\title{
Tropical tropospheric ozone derived using Clear-Cloudy Pairs (CCP) of TOMS measurements
}

\author{
M. J. Newchurch ${ }^{1}$, D. Sun ${ }^{1}$, J. H. Kim ${ }^{2}$, and X. Liu ${ }^{1,3}$ \\ ${ }^{1}$ Atmospheric Science Department, University of Alabama in Huntsville, Huntsville, Alabama \\ ${ }^{2}$ Department of Atmospheric Science, Pusan National University, Korea \\ ${ }^{3}$ Now at Harvard Smithsonian Astrophysical Observatory, Cambridge, Massachusetts
}

Received: 8 November 2002 - Published in Atmos. Chem. Phys. Discuss.: 13 January 2003

Revised: 2 May 2003 - Accepted: 28 May 2003 - Published: 11 June 2003

\begin{abstract}
Using TOMS total-ozone measurements over high-altitude cloud locations and nearby paired clear locations, we describe the Clear-Cloudy Pairs (CCP) method for deriving tropical tropospheric ozone. The high-altitude clouds are identified by measured $380 \mathrm{~nm}$ reflectivities greater than $80 \%$ and Temperature Humidity InfraRed (THIR) measured cloud-top pressures less than $200 \mathrm{hPa}$. To account for locations without high-altitude clouds, we apply a zonal sine fitting to the stratospheric ozone derived from available cloudy points, resulting in a wave-one amplitude of about 4 DU. THIR data is unavailable after November 1984, so we extend the CCP method by using a reflectivity threshold of $90 \%$ to identify high-altitude clouds and remove the influence of high-reflectivity-but-low-altitude clouds with a lowpass frequency filter. We correct ozone retrieval errors associated with clouds, and ozone retrieval errors due to sun glint and aerosols. Comparing CCP results with Southern Hemisphere ADditional OZonesondes (SHADOZ) tropospheric ozone indicates that CCP tropospheric ozone and ozonesonde measurements agree, on average, to within $3 \pm$ 1 DU standard error of the mean. The most significant difference between CCP and ozonesonde tropospheric ozone can be explained by the low Total Ozone Mapping Spectrometer (TOMS) version-7 retrieval efficiency of ozone in the lower troposphere.
\end{abstract}

\section{Introduction}

Several satellite-based methods derive tropospheric ozone distribution and variance. Each of these techniques embodies particular strengths and weaknesses. The first such method, the Tropospheric Ozone Residual (TOR) method using either Stratospheric Aerosol and Gas Experiment (SAGE) (Fish-

Correspondence to: M. J. Newchurch

(mike@nsstc.uah.edu) man and Brackett, 1997; Fishman et al., 1990) or Solar Backscatter UltraViolet (SBUV) (Fishman and Balok, 1999; Fishman et al., 1996), offers global estimates of tropospheric ozone, but suffers from uncertainty in the lower-stratospheric ozone amounts resulting from limited sampling and limited accuracy of the lower-stratospheric measurements. Deriving tropospheric ozone from TOMS data alone with some stratospheric ozone assumptions (Hudson and Thompson, 1998; Kim et al., 1996; Thompson and Hudson, 1999; Ziemke et al., 1998) suffers from uncertainty in the assumptions. The topographic contrast method (Jiang and Yung, 1996; Kim and Newchurch, 1996; Kim and Newchurch, 1998) suffers from limited spatial coverage. The scan-angle method (Kim et al., 2001) is the most direct method for extracting tropospheric ozone from the physics of the altitudinal dependence of the information in the TOMS measurement. However, this method is currently restricted to tropical latitudes where the stratospheric variability is generally small.

This paper introduces the Clear-Cloudy Pair (CCP) method to derive tropospheric ozone from TOMS measurements. This method uses column-ozone measurements above high-altitude clouds to quantify the stratospheric column ozone, similar to the Convective Cloud Differential (CCD) method (Ziemke et al., 1998). The major differences between CCD and CCP are the following: (1) The CCP approach does not assume a zonally invariant stratospheric ozone structure. Rather than using cloudy points only in the Pacific Ocean, CCP uses all high-altitude cloudy points to fit a sine curve of unconstrained amplitude and phase. (2) A reflectivity threshold of $20 \%$ is used by the CCD technique to calculate total column ozone, so some partial cloudy points will be included and may cause errors of a couple of DU, because the ozone below clouds is only a climatological estimate. However, the CCP method uses a reflectivity threshold of the actual clear-sky reflectivity plus $5 \%$ to identify clear-sky points and to calculate total column ozone. (3) The CCD technique uses the minimum ozone above high-reflectivity clouds 

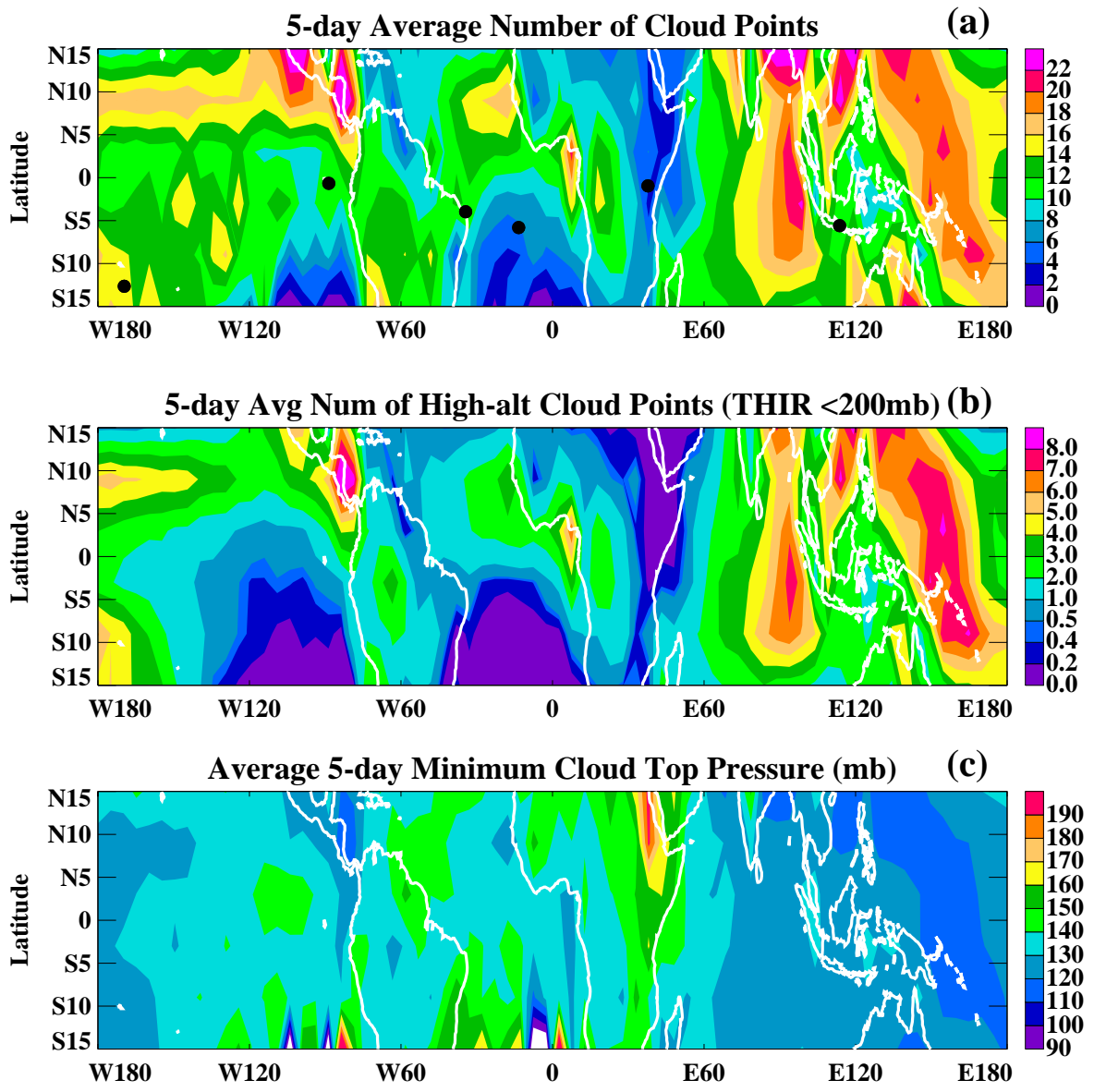

Fig. 1. (a) The average number of cloud points (reflectivity $>80 \%$ ) in each $5^{\circ}$ by $5^{\circ}$ box for each five-day period during $1979-1984$; (b) the average number of high-altitude cloud points (reflectivity $>80 \%$ and THIR $<200 \mathrm{hPa}$ ) in each $5^{\circ}$ by $5^{\circ}$ box for each five-day period during 1979-1984; and (c) The average five-day minimum cloud top pressure (hPa) during 1979-1984.

in one month to represent the stratospheric ozone for that month, while the CCP method averages the minimum ozone amounts above high-altitude clouds for each five-day period in one month to represent the stratospheric ozone for that month. (4) The effects of high-reflectivity-but-low-altitude clouds and cloud anomaly are estimated and included in CCP method.

On average, the zonal sine-wave fitting results in a longitudinal stratospheric wave-one with an average amplitude of $\sim 4 \mathrm{DU}$ and a peak near the Prime Meridian, consistent with the wave structure of stratospheric ozone as mentioned by Ziemke et al. (1998) and described by Newchurch et al. (2001b) where the tropical stratospheric ozone is not zonally invariant, but follows a wave-1 pattern with an average monthly amplitude of $\sim 4$ DU. A wave- 1 fit represents a first-order approximation to a phenomenon that probably contains higher order wave numbers. Part of the discrepancy between the stratospheric wave- 1 pattern found by Newchurch et al. (2001) using 5-day means and other researchers using monthly averages of stratospheric measurements may be explained by the potential effect of tropical Kelvin waves or equatorial Rossby waves that will not be apparent in monthly averages. Subsequent correction for TOMS retrieval artifacts reduces the amplitude by about the half (see Sect. 5.3). Compared to the typical value of tropospheric ozone of 20 30 DU, this average corrected wave1 amplitude of 2 DU (Peak-to-trough difference of $\sim 4 \mathrm{DU}$ with monthly excursions exceeding $5 \mathrm{DU}$ ) cannot be neglected. We use the Temperature Humidity Infrared Radiometer (THIR) measurements (Stowe et al., 1988) collocated with TOMS measurements on the NIMBUS-7 platform to assess both the true altitude of the reflecting clouds and the accuracy of using the TOMS measurement of reflectivity at $380 \mathrm{~nm}$ alone as a proxy for cloud altitude. Comparisons of the CCP tropical tropospheric ozone columns to the available ozonesonde record indicate an improvement of about $6 \mathrm{DU}$ with respect to the archived CCD data from http://code916.gsfc.nasa.gov/People/Ziemke/ averaged over all available SHADOZ ozonesonde observations. Ziemke et al. (1998) recommended adjusting the archived CCD value by 5 DU based on Nimbus-7/Earth Probe TOMS total column ozone differences; however, we use only the archived values here (use archived data without subtracting 5 DU). 


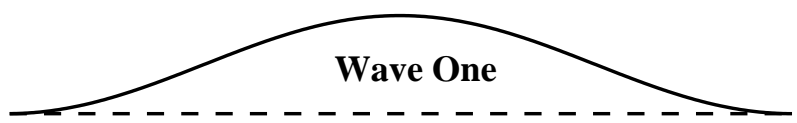

Background Stratospheric Ozone

$\begin{array}{lllll}-180 & -90 & 0 & 90 & 180\end{array}$

Fig. 2. Schematic showing the construction of the stratospheric ozone column. The background stratospheric column ozone results from the TOMS measured ozone column above high-altitude clouds in the Pacific Ocean area for individual latitudes, and the zonal wave-1 phase of stratospheric column ozone is computed from ozone above high-altitude clouds between $5^{\circ}$ and $10^{\circ}$ North latitude and between $0^{\circ}$ and $5^{\circ}$ North latitude at all longitudes. The wave- 1 phase and amplitude are resulted from fitting all data and are not constranied by any a prior assumption.

\section{Data description}

The CCP method uses NIMBUS-7 TOMS version-7 Level2 daily global measurements from November 1978 to May 1993 and Earth Probe TOMS measurements from July 1996 to 2000. The THIR cloud pressure, coincident with the NIMBUS-7 TOMS observations, is available from November 1978 to November 1984. These infrared cloud-top measurements, which in conjunction with National Center for Environmental Protection (NCEP) temperature profiles produce cloud-top heights reported on the Level-2 Version7 TOMS data files, are adjusted as in (Newchurch et al., 2001b) (described below). The noise equivalent temperature of THIR instrument at $11.5 \mathrm{um}$ and $185 \mathrm{~K}$ (the typical temperature of tropical upper-troposphere) is $1.5^{\circ}$ (Hwang, 1982). Because the THIR-measured equivalent blackbody temperature is compared with the local monthly temperature profile to derive the cloud top pressure, the accuracy of the derived cloud top pressure depends on the vertical variance of temperature profile. However, at the wet adiabatic lapse rate of $6.5 \mathrm{~K} / \mathrm{km}$, a THIR uncertainty of $1.5 \mathrm{~K}$ amounts to only $1 / 4 \mathrm{~km}$ cloud top altitude uncertainty. That altitude uncertainty corresponds to ozone amounts less than 1 DU. Ozone retrieval errors due to sun glint (McPeters et al., 1996) and tropospheric aerosols (Torres and Bhartia, 1999) are corrected using the Dave reflectivity code (Personal communication with C. G. Wellemeyer, 1999). In order to validate the results derived from our method, we used the following SHADOZ ozonesonde data: Samoa (14S, 171W; 1998-1999), Cristobal (1S, 90W; 1998-2000), Natal (5S, 35W; 1998-1999), Ascension Island (8S, 15W; 1998-2000), Nairobi (1S, 37E; 1998-2000), and Java (8S, 113E; 19982000) (Thompson and Witte, 1999; Thompson et al., 2001).

The THIR data embedded in the TOMS dataset often reports cloud-top pressures between $60-80 \mathrm{hPa}$ and some- times lower. These pressures correspond to altitudes significantly higher than the typical tropical tropopause pressure of $\sim 100 \mathrm{hPa}$. Comparing these values to the only available two months of revised THIR pressures reveals that the archived values for pressures less than $200 \mathrm{hPa}$ are always too low. In order to use the six years of archived THIR data (19791984), we scaled the archived values to higher pressures according to the relationship shown in Fig. 1 in (Newchurch et al., 2001b)

\section{Cloudy point distribution}

Using the THIR observations from the NIMBUS-7 platform, Fig. 1a shows the number of high-reflectivity cloud points (reflectivity $>80 \%$ ) in every $5^{\circ}$ by $5^{\circ}$ region within fiveday periods averaged over 1979 1984. The Indian Ocean and Pacific Ocean areas experience a high frequency of cloud points while the South Atlantic experiences a low frequency of clouds. Figure $1 b$ indicates the average number of high-altitude cloud points (reflectivity $>80 \%$ and THIR $<200 \mathrm{hPa}$ ) that are included in Fig. 1a. We can see that the west Pacific and the east Indian oceans have the largest number of high-altitude cloud points, $\sim 2-7$, and the south Atlantic Ocean, the southeast Pacific Ocean, and east of Africa experience almost no high-altitude cloud points, $\sim 0$ 2. Not only the west Pacific, but also most tropical areas have high-altitude cloudy points available to calculate stratospheric ozone. Therefore, it is possible to use all cloudy points to derive tropospheric ozone, instead of cloudy points only in the west Pacific as in the CCD method. Figure 1c displays the average five-day minimum cloud top pressure, and most areas correspond to average cloud-top pressures of $110-140 \mathrm{mb}$, close to the climatological tropical tropopause of $100 \mathrm{mb}$; however, east Africa and the area between $15^{\circ}$ south latitude, $10^{\circ}$ south latitude, $120^{\circ}$ west longitude, and $10^{\circ}$ east longitude correspond to low-altitude clouds. Therefore, we exclude those cloudy points when we calculate the CCP tropospheric ozone.

\section{Clear-Cloudy Pair method}

In the Clear-Cloudy Pair method, tropospheric ozone results from the difference between the total column ozone at clear-sky points and the stratospheric ozone column at paired cloudy-sky points when the cloud top reaches the tropopause.

\subsection{Calculate Stratospheric Column Ozone}

Figure 2 is a diagram of the stratospheric column ozone derivation where stratospheric ozone is regarded as a combination of a zonal flat background and a zonal wave 1 of unconstrained a priori phase and amplitude. Over five-day periods, for each $5^{\circ}$-longitude by $5^{\circ}$-latitude box between $15^{\circ} \mathrm{N}$ and $15^{\circ} \mathrm{S}$ except boxes in east Africa and between $15^{\circ}$ 

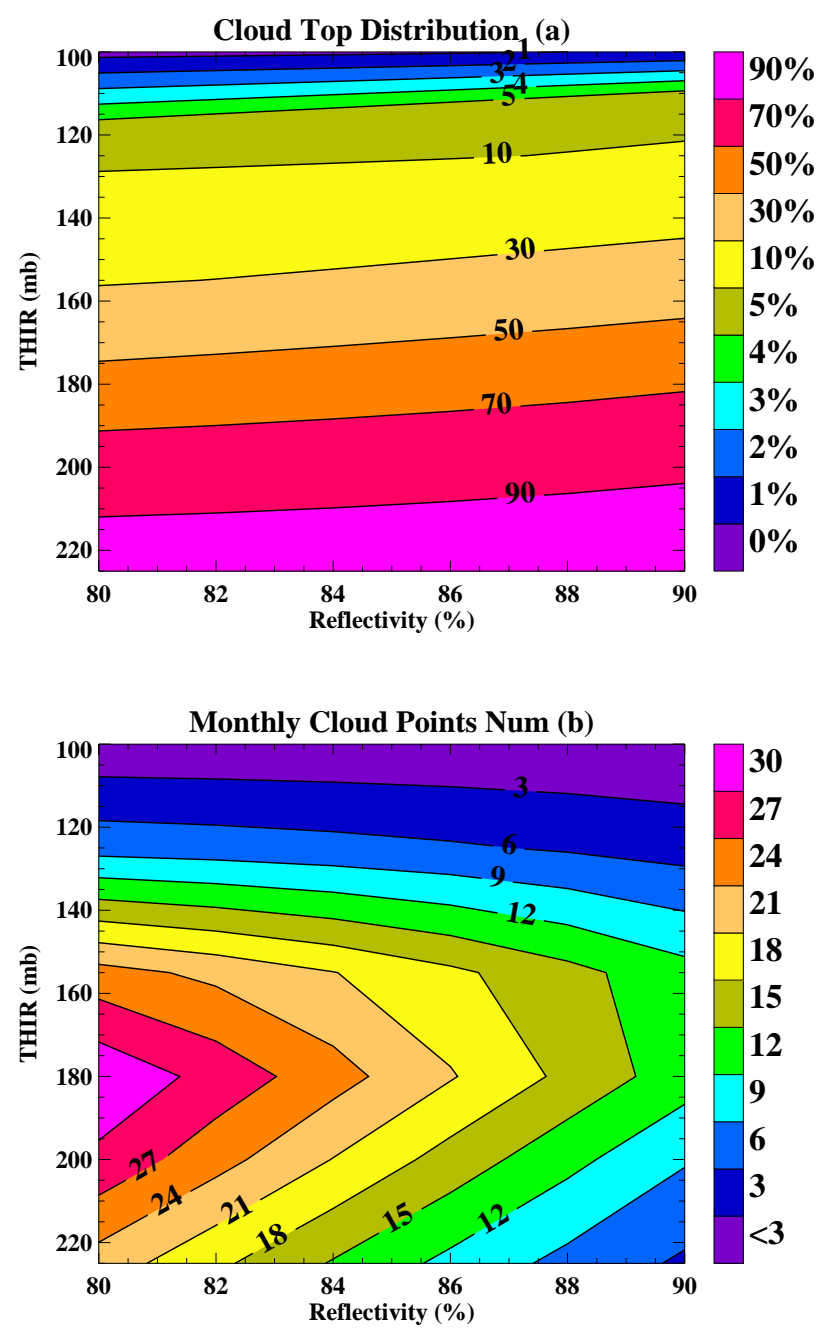

Fig. 3. (a) The THIR cloud-top distribution as a function of reflectivity for pressures less than $225 \mathrm{hPa}$, and (b) the monthly average number of cloud points between 1979-1984 as functions of THIR pressure and reflectivity.

south latitude, $10^{\circ}$ south latitude, $120^{\circ}$ west longitude, and $10^{\circ}$ east longitude, which correspond to low-altitude clouds, we choose all the high-altitude cloudy-sky observations from TOMS measurements and choose the minimum of all ozone column above those clouds as the CCP estimate of stratospheric ozone in each grid box. As shown in Fig. 1, the zone between $5^{\circ} \mathrm{N}$ and $10^{\circ} \mathrm{N}$ and the zone between $0^{\circ} \mathrm{S}$ and $5^{\circ} \mathrm{S}$, corresponding to relatively even distribution of high-altitude cloud occurrence as in (Newchurch et al., 2001b), provides useful cloudy points to derive the phase of the stratospheric ozone wave. Every zone other than the $5^{\circ} \mathrm{N}$ to $10^{\circ} \mathrm{N}$ latitude zone and the $0^{\circ} \mathrm{S}$ to $5^{\circ} \mathrm{S}$ latitude zone contains insufficient cloudy points to estimate the stratospheric ozone phase. Therefore, we apply the phases derived from the $5^{\circ} \mathrm{N}$ to $10^{\circ} \mathrm{N}$ latitude zone and from the $0^{\circ} \mathrm{S}$ to $5^{\circ} \mathrm{S}$ latitude zone to each zone in the Northern Hemisphere and Southern Hemisphere, respectively. The derived phase is used in the sine fitting to all available stratospheric ozone values in each zone to derive the stratospheric ozone.

To identify high-altitude clouds with tops reaching the tropopause, we employ the following criteria: (a) $380 \mathrm{~nm}$ measured reflectivity is greater than $80 \%$, because the TOMS Version-7 algorithm assumes that reflectivity greater than $80 \%$ implies a completely cloudy pixel (McPeters et al., 1996), and (b) THIR-derived cloud-top pressure is less than $200 \mathrm{hPa}$ (after adjustment). Those criteria cannot guarantee that all clouds have reached the tropopause, but because few clouds penetrate the tropopause, the minimum of all column ozone above the clouds in each grid box will correspond to the cloud closest to the tropopause. Instead of using monthly minimum of ozone above high-reflectivity clouds, the CCP technique chooses these five-day minimum ozone values above high-altitude clouds and then applies the sine wave-1 fitting to the monthly average value to get the stratospheric ozone for the entire zone.

\subsection{Calculate Total Column Ozone}

Based on the TOMS algorithm, completely clear-sky points have reflectivity of less than $8 \%$ (McPeters et al., 1996). However, insufficient $8 \%$ reflectivity points are available to calculate the entire map of tropical total-column ozone, particularly in continental areas. In order to acquire sufficient clear-sky points, we first calculate the surface reflectivity as described in (Herman et al., 2001; Herman and Celarier, 1997). Then we calculate the monthly average total column ozone at each $5^{\circ}$ by $5^{\circ}$ box with points having reflectivity less than $5 \%$ above the surface reflectivity.

The CCP tropospheric column ozone then results from subtracting, for each five-day period, the stratospheric ozone from total ozone at each $5^{\circ}$ by $5^{\circ}$ box. Calculating the fundamental CCP stratospheric column ozone over five-day periods accounts for most of the perturbations of stratospheric ozone caused by Kelvin waves and Rossby-Gravity waves (Smith and Riese, 1999; Stanford et al., 1996; Ziemke and Stanford, 1994), which typically have periods longer than five days. We average these five-day samples of the stratospheric ozone over one-month periods to reduce the random error and to increase the spatial coverage.

\section{Errors in CCP technique and correcting mechanism}

The accuracy of CCP tropospheric ozone depends on the accuracy of TOMS total column ozone, the accuracy of the ozone above the clouds, and the correspondence of highaltitude cloud tops to the tropopause. Unfortunately, none of those three elements is perfect, so errors propagate into the derived CCP tropospheric ozone. 


\subsection{Lower tropospheric ozone retrieval efficiency}

The retrieval efficiency error is a well-known and welldocumented physical retrieval phenomenon that results from the less-than-perfect transmission of photons from the troposphere up to the space-borne instrument (Hudson et al., 1995; Kim et al., 1996; Kim et al., 2001). The magnitude of this error increases as the difference (in either direction) between actual and assumed tropospheric ozone from the TOMS algorithm increases. When the actual tropospheric ozone amount is higher than the assumed tropospheric ozone amount, TOMS underestimates column ozone. However, if actual tropospheric ozone amount is smaller than the assumed amount, TOMS overestimates column ozone. This phenomenon of imperfect tropospheric ozone sensing is also manifest in the situation described by (Wellemeyer et al., 1997) that shows the overestimation of TOMS total ozone at high latitude due to profile-shape error. The work of (Martin et al., 2001) also corroborates this relationship between the efficiency factor and the a priori profile. This adjustment is not offered as a "fix" to the CCP results, but only as a calculation to understand the effect of the TOMS retrieval efficiency. Such an adjustment clearly requires knowledge of the true profile, which in general is an unknown quantity. The CCP dataset is archived at (http://vortex.nsstc.uah.edu/atmchem) without this efficiency adjustment, but the authors recommend the user combine the CCP tropospheric ozone and the correction of TOMS retrieval efficiency derived by (Martin et al., 2001) as the actual tropospheric ozone. This efficiency correction applies to version 7. The next TOMS data release, version 8 , will incorporate an internal efficiency correction.

Correcting the retrieval efficiency effect requires the actual TOMS tropospheric ozone retrieval efficiency profile that depends on the actual tropospheric ozone profile, scan angle, solar zenith angle, and surface reflectivity. This connection is complex; however, an approximate method is available now. Using climatological tropospheric ozone profiles and typical scan angle, solar zenith angle, and surface reflectivity, we run the TOMS radiative code and calculate the typical tropospheric ozone retrieval efficiency as 0.66. Therefore, TTO (Tropical Tropospheric Ozone) $)_{\text {actual }}=\mathrm{CCP}_{\text {measure }}+$ $(1-0.66)^{*}\left(\mathrm{TTO}_{\text {actual }}-33.8\right)$, where 33.8 is the climatological tropospheric ozone used in the TOMS algorithm. From the above formula, we get the corrected TTO $=\left(\mathrm{CCP}_{\text {measure }}\right.$ $\left.-33.8^{*} 0.34\right) / 0.66$.

\subsection{Difference between cloud top and tropopause}

As shown in Fig. 1c, the five-day average highest cloud top is lower than the tropopause. This difference will introduce a tropospheric ozone underestimate of about 3 DU as estimated in (Newchurch et al., 2001b). Fortunately, this ozone difference is almost independent of longitude in tropical areas, as described in (Newchurch et al., 2001b); therefore, it will not significantly affect the analysis of zonal CCP tro- pospheric ozone. The latitudinal influence is not estimated because there is insufficient data.

\subsection{The anomaly of ozone above the clouds}

The third error source in the CCP method is the consistent large cloudy/clear total ozone difference between cloudy areas and clear areas after one corrects errors induced by incorrect cloud-heights (Liu et al., 2002). Analysis indicates that the remaining cloudy/clear total ozone difference resulting from convection and enhanced chemical ozone production rate above the clouds is negligible, suggesting that the remaining cloudy ozone excess is mainly a result of ozone absorption inside the cloud. Direct estimation of the influence of Ozone Above Clouds (OZAC) due to ozone inside the clouds requires the knowledge of the ozone's distribution in the cloud and the cloud's complex optical structure. Detailed calculation of the ozone's influence inside clouds is outside the scope of this paper. However, the analysis of the cloudy/clear total ozone difference provides an indirect way of estimating the effects related to clouds.

As described in (Liu et al., 2002), errors in OZAC due to incorrect cloud height range from $-10.7 \mathrm{DU}$ to $-1.4 \mathrm{DU}$, with an average error of $-3.9 \pm 1.5 \mathrm{DU}$. Because of the incorrect climatological tropospheric ozone used in the TOMS algorithm, the added ozone below clouds has an error due to the difference between the actual and climatological ozone below cloud tops, and the clear-sky total ozone suffers from the lower retrieval efficiency for lower tropospheric ozone. To address those two problems, the monthly mean SHADOZ tropospheric profile is used and regarded as independent of latitude within the southern hemisphere and interpolated across the longitude to obtain the approximate true data for any tropical region. The approximate data in the Northern Hemisphere is six months out of phase with that in the Southern Hemisphere. We compute errors in each $50 \mathrm{mb}$ layer using the height-resolved retrieval efficiency factors and integrate errors from surface pressure to monthly mean cloudtop pressure. The corrections range from $-15 \mathrm{DU}$ to $15 \mathrm{DU}$ for cloudy total ozone scenes. The remaining cloudy/clear total ozone difference after accounting for errors from incorrect tropospheric climatology is ascribed to errors due to ozone absorption enhancement in the clouds, the assumption of Lambertian cloud surfaces, and other unknown errors. The result of these corrections is to reduce the amplitude of the stratospheric ozone wave 1 by a factor of two, on average.

No THIR data is available in the EP TOMS period. We reason that the errors induced by incorrect cloud height and incorrect tropospheric climatology are similar for both Nimbus-7 and EP TOMS. However, there is a consistent offset in cloudy/clear total ozone difference between Nimbus-7 and EP TOMS data (Newchurch et al., 2001a; Ziemke and Chandra, 1999). The cloudy/clear total ozone difference in the EP-TOMS period is about 4.3 DU smaller than that of the Nimbus-7 TOMS period. This offset varies little with latitude 
Lat: 7.5 Lon: $\mathbf{- 1 7 2 . 5}$
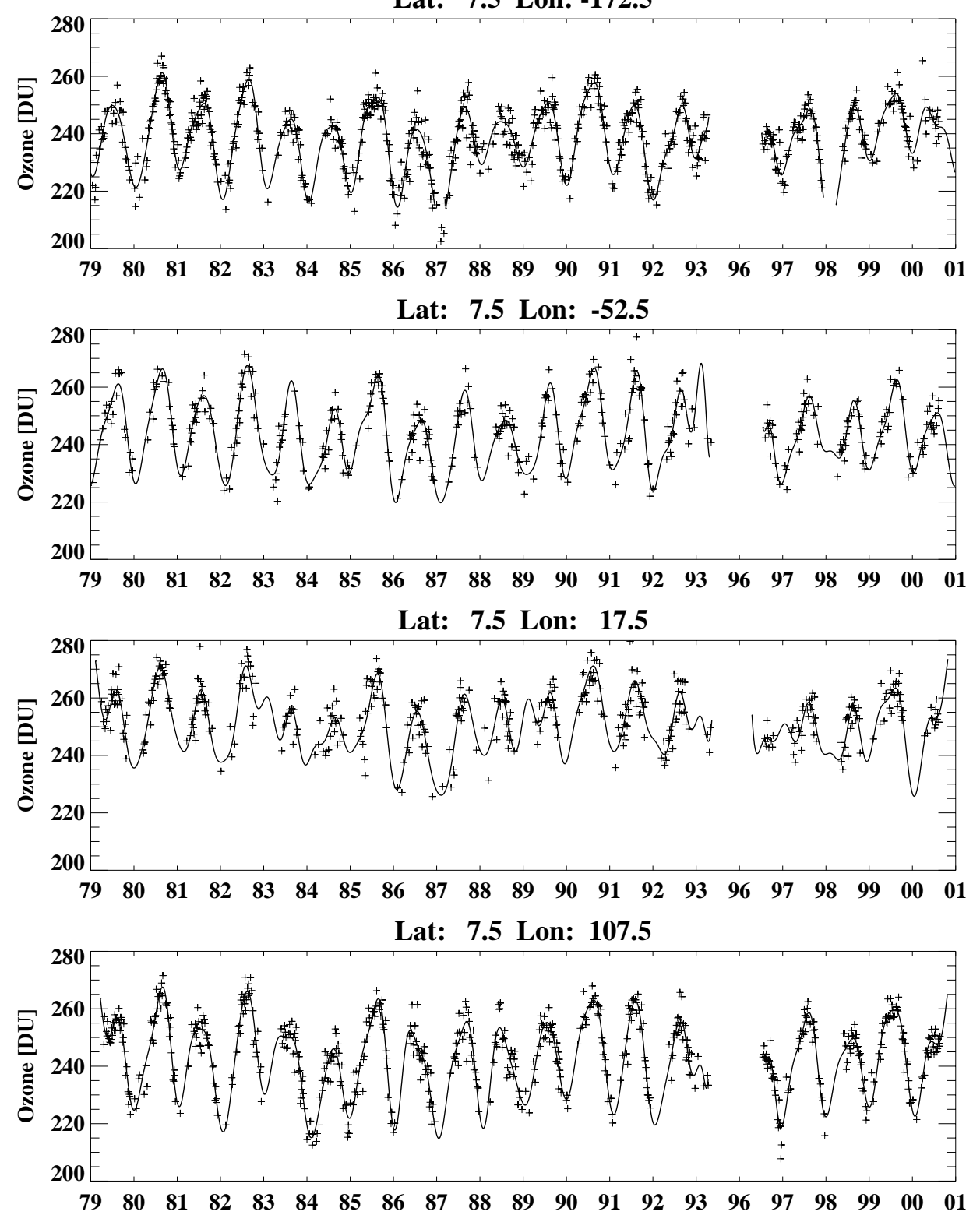

Fig. 4. Time series of column ozone above clouds and their lowpass filtered values at four locations distributed longitudinally at $7.5^{\circ} \mathrm{N}$.

and season, and the reason for this Nimbus-7/EP offset is not currently clear; however, release of version 8 may show that Raman scattering by the $\mathrm{O}_{2}$ dimer at $360 \mathrm{~nm}$ is responsible for this offset. As a result, the cloudy anomaly correction for EP-TOMS is 4.3 DU smaller, on average, than the Nimbus7 correction. Because this cloud anomaly correction should apply to all clear-cloudy difference methods, we apply it to the CCD method (Ziemke et al., 1998) for purposes of comparison to SHADOZ observation (Sect. 7). This difference in the anomaly correction between Nimbus-7 / EP TOMS is of the same magnitude and sign as the Nimbus-7/EP TOMS offset in total column ozone seen by (Ziemke and Chandra,
1999) and may result from the same fundamental cause. We subtract a constant 4.3 DU from the error in OZAC derived from 1979-1984 to approximate the OZAC error during the EP-TOMS period.

\section{Tropospheric ozone derivation without THIR}

Because THIR data is unavailable after November 1984, we cannot determine the actual cloud top altitude. However, the TOMS 380-nm reflectivity measurements provide some information to discern cloud altitude. Figure $3 \mathrm{a}$ indicates that, in general, more highly reflecting clouds occur at lower 

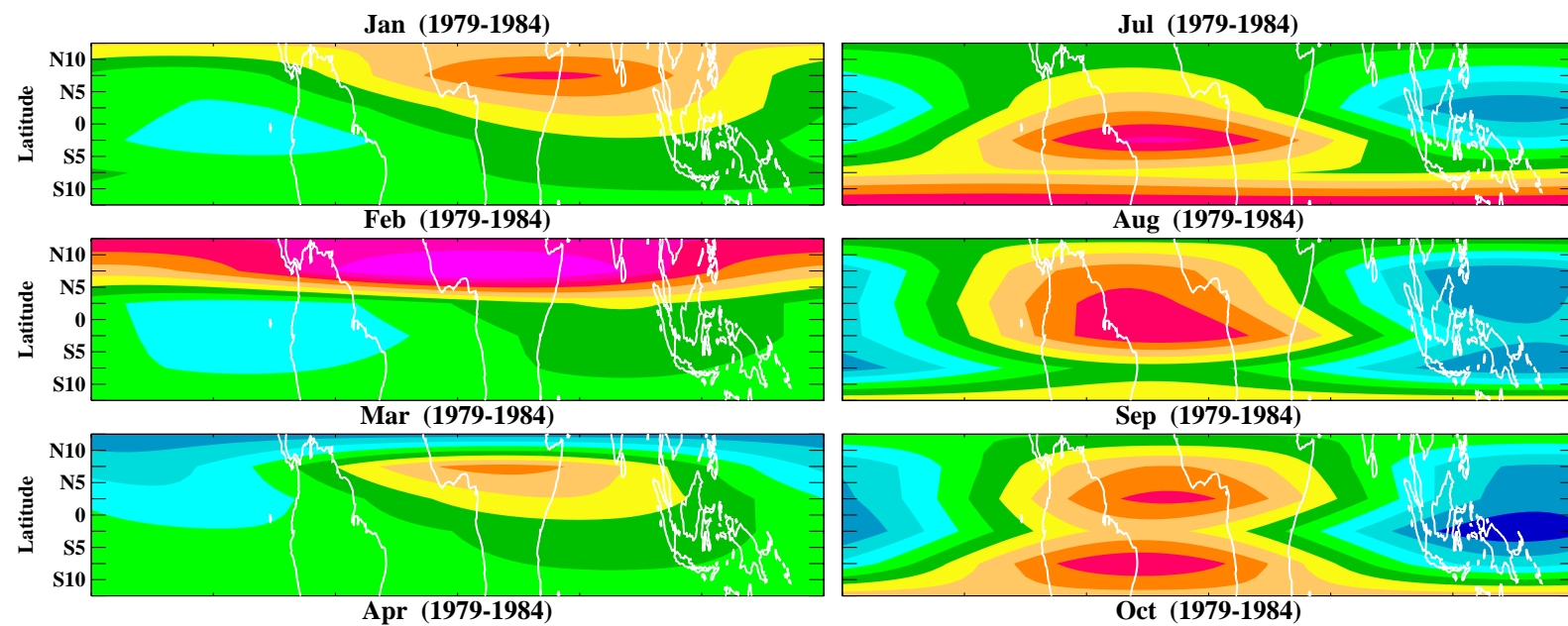

DU
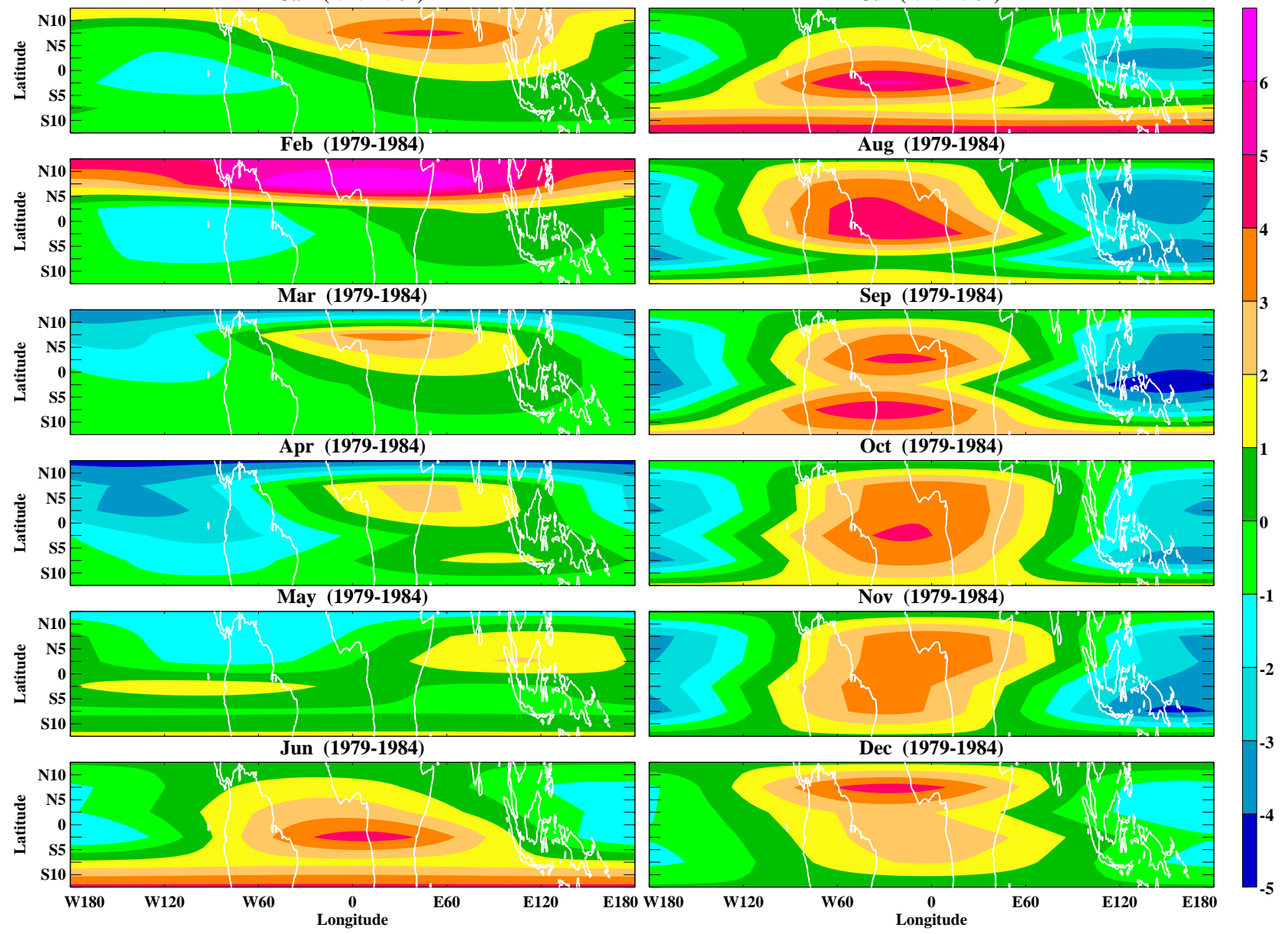

Fig. 5. Average monthly difference (THIR CCP minus No-THIR CCP) between tropospheric ozone derived from the CCP method with THIR and without THIR cloud data over 1979-1984.

pressures, as previously reported (Eck et al., 1987; Stowe et al., 1988). For reflectivities greater than $80 \%$, almost all the clouds (90\%) occur at altitudes above $210 \mathrm{hPa}$ (within $\sim 100 \mathrm{hPa}$ of the tropopause). Most cloud-top pressures correspond to $160-200 \mathrm{hPa}$ (Fig. 3b). These distributions vary somewhat with month, year, and location.

To remove low-altitude cloud points and to provide a continuous record at all grid points, we apply a lowpass frequency filter to the time series of ozone observations above high-reflectivity $(90 \%)$ cloud points for each $5^{\circ}$ by $5^{\circ}$ grid cell over 20 years. Figure 4 displays examples of the pentad values from four grid cells of the ozone above cloudy points and the ozone column value resulting from the lowpass filter using a minimum frequency of two months. This lowpass filter is essentially a smoothing function that provides a continuous time series at every grid cell and reduces the extreme values, especially the value corresponding to highreflectivity-but-low-altitude clouds. One limitation of this filtering technique is the presence of end effects in the first and last $1 / 4$ cycles ( 1 st and last 3 months) that will either increase or decrease the derived tropospheric ozone, perhaps by as much as $15 \mathrm{DU}$ at some locations. The CCP tropospheric ozone then results from the process described in Sections 4 and 5 .

In addition to the errors identified in section 5, another error source exists in the no-THIR CCP method; that is the difference of stratospheric ozone quantified by both reflectivity and THIR compared to ozone derived from reflectivity only. Figure 5 shows the difference (THIR CCP minus NoTHIR CCP) tropospheric ozone over 1979-1984, the period when both THIR data and reflectivity data are available. The difference in the Pacific Ocean is negative, and the differences in the Atlantic and African areas usually correspond to positive values. The positive differences have a strong dependence on the seasonal InterTropical Convergence Zone (ITCZ) movement. In the ITCZ area the difference is small; otherwise, the difference is larger. However, the difference is within about $4 \mathrm{DU}$ nearly everywhere; therefore, the extended CCP method (using reflectivity observations without THIR measurements) may cause errors with typical value of 

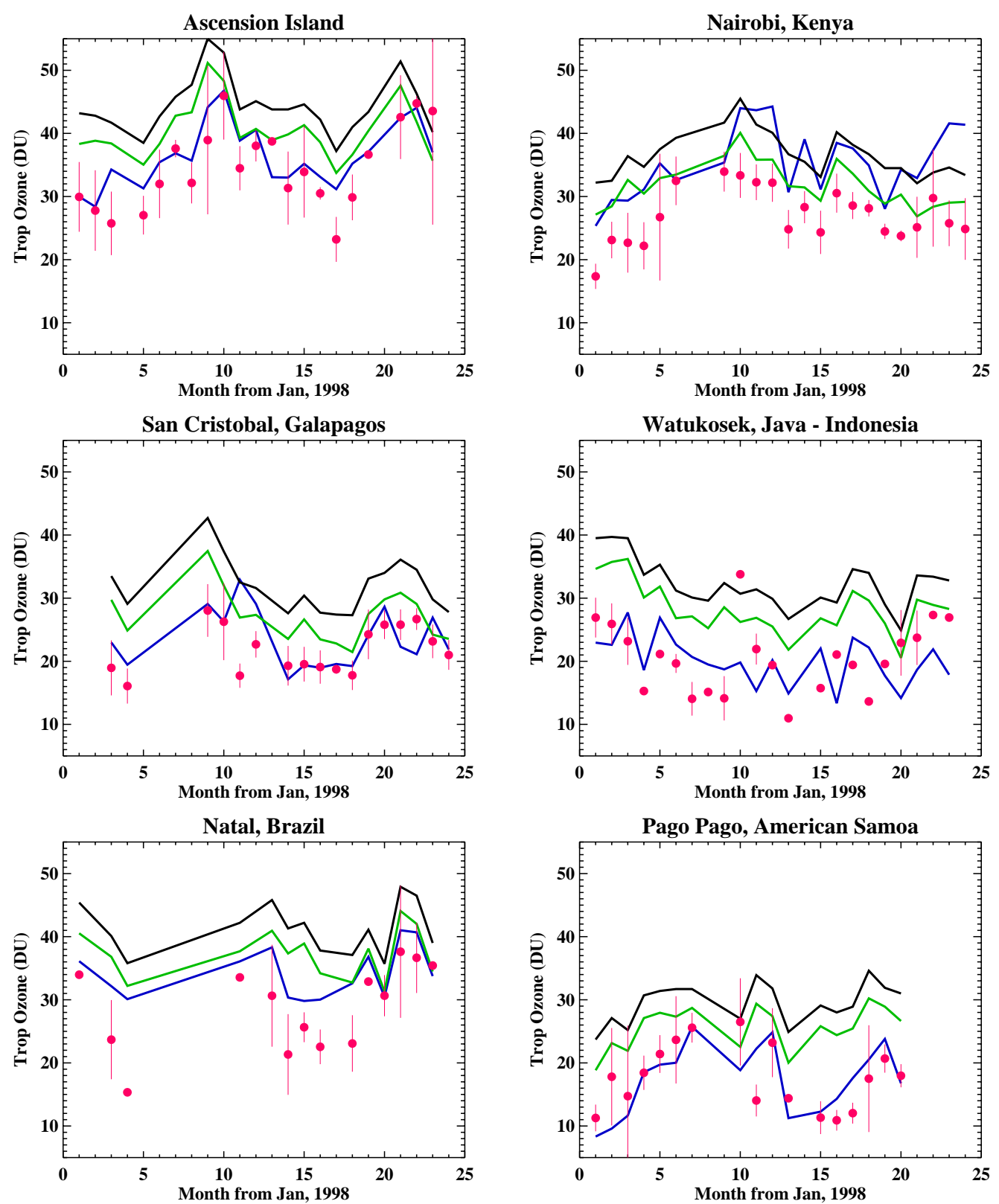

Fig. 6. Comparison of CCD and CCP tropospheric ozone with SHADOZ tropospheric ozone from 1998-2000 at six sites. Red circles are the sonde integrated tropospheric ozone columns, vertical bars represent 1 SD of the ozonesonde monthly mean, black lines represent the CCD tropospheric columns, blue lines represent the derived CCP tropospheric columns, and green lines are the CCD results after applying the correction from the cloud anomalies offset between Nimbus-7 / EP TOMS.

4DU. We have included this difference in the derived CCP tropospheric ozone to reduce the error related to low-altitude clouds.

\section{Accuracy assessment of CCP}

The comparison results of the CCP and CCD appear in Fig. 6 along with the ozonesonde monthly means \pm 1 standard deviation. The tropopause is determined using WMO tropopause definition when integrating sonde tropospheric ozone. To quantify the comparison we show the station mean differences \pm 1 standard deviation and 1 standard error of the mean in Table 1. The mean the of difference between SHADOZ and CCP across all stations is $0 \pm 1$ DU SEM. From station to station, the mean difference varies from $-4 \mathrm{DU}$ at Ascension to $1 \mathrm{DU}$ at Samoa and San Cristobal. These mean differences are significantly smaller than the SHADOZ-CCD biases of 9 \pm 1 SEM. 

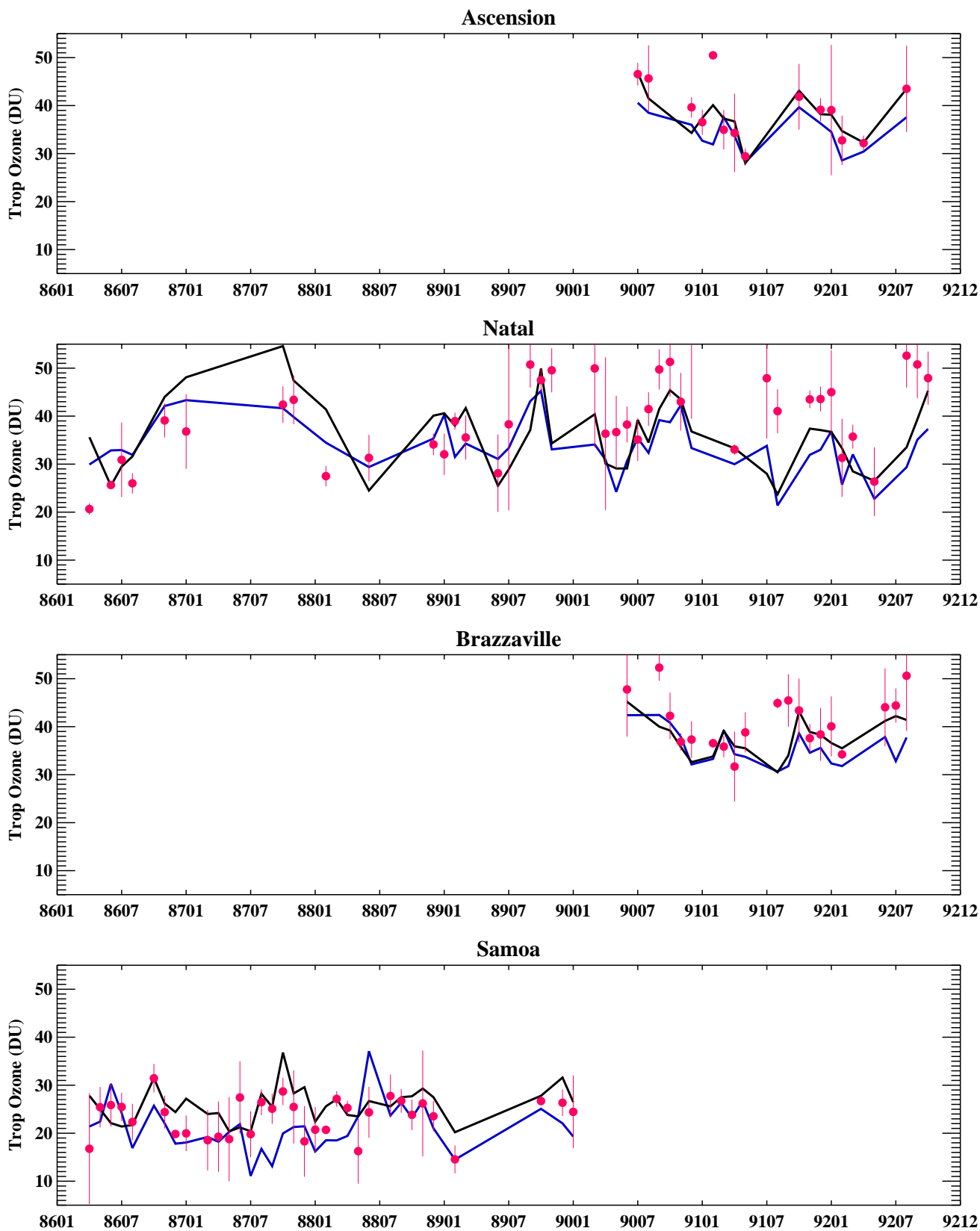

Fig. 7. Comparison of Nimbus-7 CCD and CCP tropospheric ozone with sonde measurements at four stations - Ascension Island, Natal, Brazzaville, and Samoa - over 1986-1992. Red circles are the sonde integrated tropospheric ozone columns, vertical bars represent 1 SD of the ozonesonde monthly mean, black lines represent the CCD tropospheric columns, and blue lines represent the derived CCP tropospheric columns.

The cloud anomaly offset between Nimbus-7 and EP TOMS (cloudy/clear total ozone difference between Nimbus7 and EP TOMS) discussed in Sect. 5.3 also works with the CCD technique because it uses cloud points to calculate stratospheric ozone as well. The green lines in Fig. 6 indicate the CCD values that resulted with this offset correction, which significantly improves the comparison of SHADOZ and CCD tropospheric ozone in all stations.
Nimbus-7 TOMS CCP and CCD tropospheric ozone is compared to ozonesonde observations between 1986-1992 in Fig. 7. At all stations Ascension Island, Natal, Brazzaville and Samoa, both CCP and CCD are comparable to ozonesonde measurements.

The CCD method described by (Ziemke et al., 1998) also uses high-altitude clouds to determine the stratospheric ozone column for subtraction from the total ozone to derive 

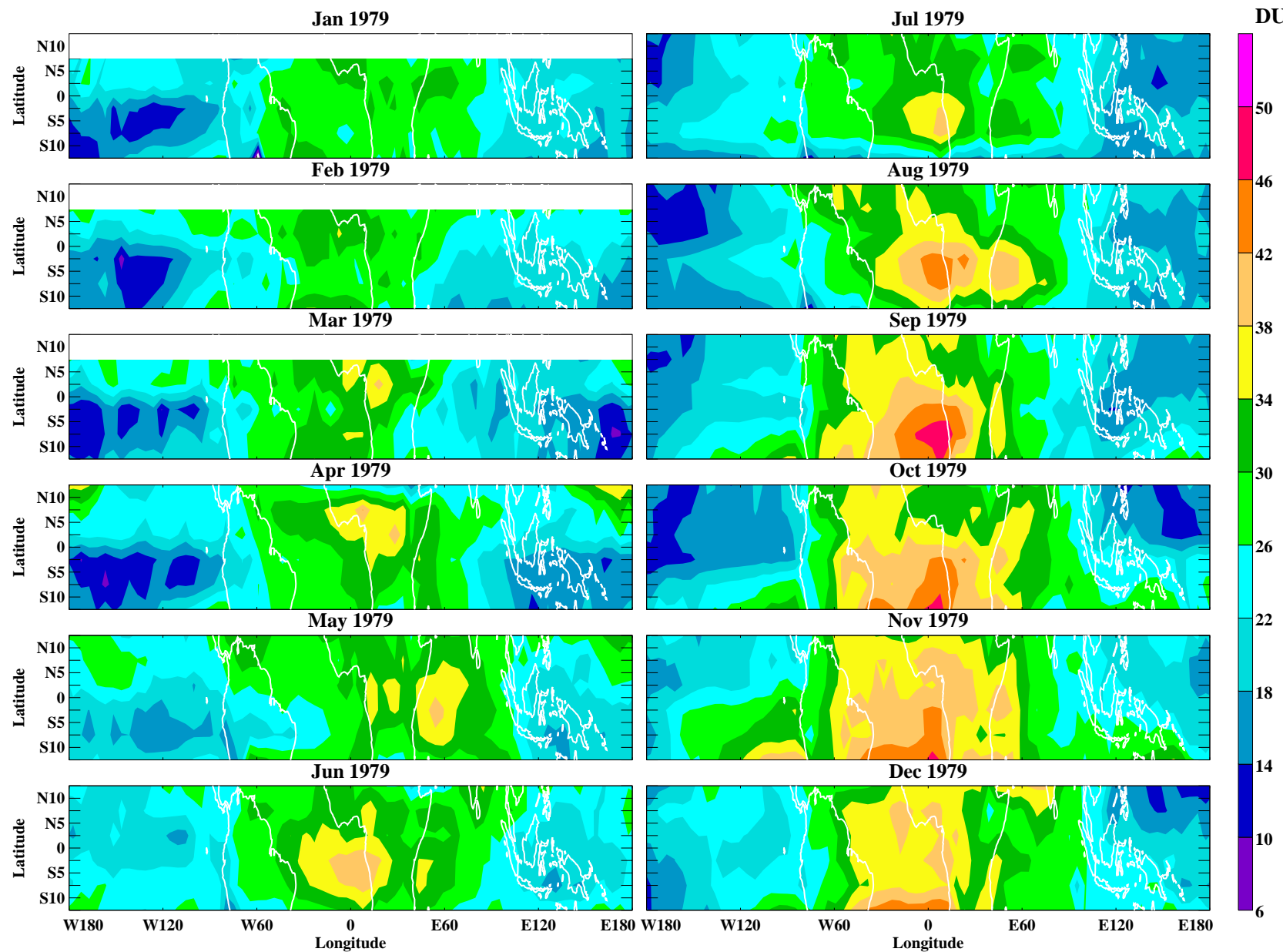

Fig. 8. CCP tropospheric ozone derived with THIR cloud-height and Nimbus-7 TOMS 380-nm reflectivity information in 1979.

Table 1. The Average Differences in \% (CCx - SHADOZ) \pm 1 Standard Deviation (sd) and Standard Errors Of The Mean (SEM) Differences Between CCx and SHADOZ Tropospheric Ozone. The CCD data are from http://code916.gsfc.nasa.gov/People/Ziemke/ without any subtraction for NIMBUS-7/EP TOMS offset. CCD' refers to the corrected CCD with the clear/cloud total column ozone difference of N7/EP TOMS, but without the 5 DU subtraction from EP TOMS based on a clear-sky total ozone column offset between NIMBUS-7 and EP TOMS.

\begin{tabular}{ccccccc}
\hline $\begin{array}{c}\text { SHADOZ } \\
\text { Station }\end{array}$ & $\begin{array}{c}\text { CCP-SHADOZ } \\
\pm 1 \text { sd }\end{array}$ & $\begin{array}{c}\text { CCP-SHADOZ } \\
\text { SEM }\end{array}$ & $\begin{array}{c}\text { CCD-SHADOZ } \\
\pm 1 \text { sd }\end{array}$ & $\begin{array}{c}\text { CCD-SHADOZ } \\
\text { SEM }\end{array}$ & $\begin{array}{c}\text { CCD'-SHADOZ } \\
\pm 1 \text { sd }\end{array}$ & $\begin{array}{c}\text { CCD'-SHADOZ } \\
\text { SEM }\end{array}$ \\
\hline Ascension & $2 \pm 4$ & 1 & $7 \pm 5$ & 1 & $6 \pm 5$ & 1 \\
San Cristobal & $2 \pm 5$ & 1 & $8 \pm 3$ & 1 & $5 \pm 3$ & 1 \\
Natal & $5 \pm 4$ & 2 & $10 \pm 6$ & 2 & $8 \pm 5$ & 2 \\
Nairobi & $8 \pm 4$ & 1 & $7 \pm 3$ & 1 & $5 \pm 3$ & 1 \\
Java & $0 \pm 6$ & 1 & $10 \pm 6$ & 1 & $8 \pm 6$ & 1 \\
Samoa & $0 \pm 4$ & 1 & $11 \pm 4$ & 1 & $8 \pm 5$ & 1 \\
Average & $3 \pm 5$ & 1 & $9 \pm 5$ & 1 & $7 \pm 5$ & 1 \\
\hline
\end{tabular}

tropospheric ozone. That method assumes the tropical stratospheric ozone is zonally invariant and is determined by the monthly mean of minimum ozone above high-reflectivity (reflectivity $\geq 90 \%$ ) clouds in each $5^{\circ}$ by $5^{\circ}$ region across the Pacific Ocean from $120^{\circ} \mathrm{E}$ to $120^{\circ} \mathrm{W}$. However, the CCD method does not correct the error due to clouds, and it uses the monthly minimum ozone average over the west Pacific Ocean rather than the five-day minimum ozone over all tropical area used in CCP method. The CCD archived values typically report 7-11 DU more tropospheric ozone than does the 

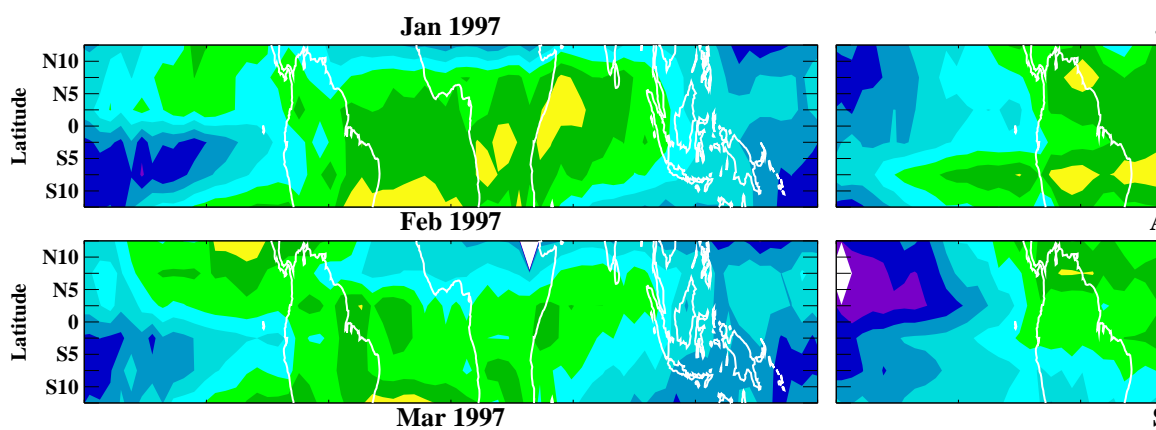

Jul 1997

DU
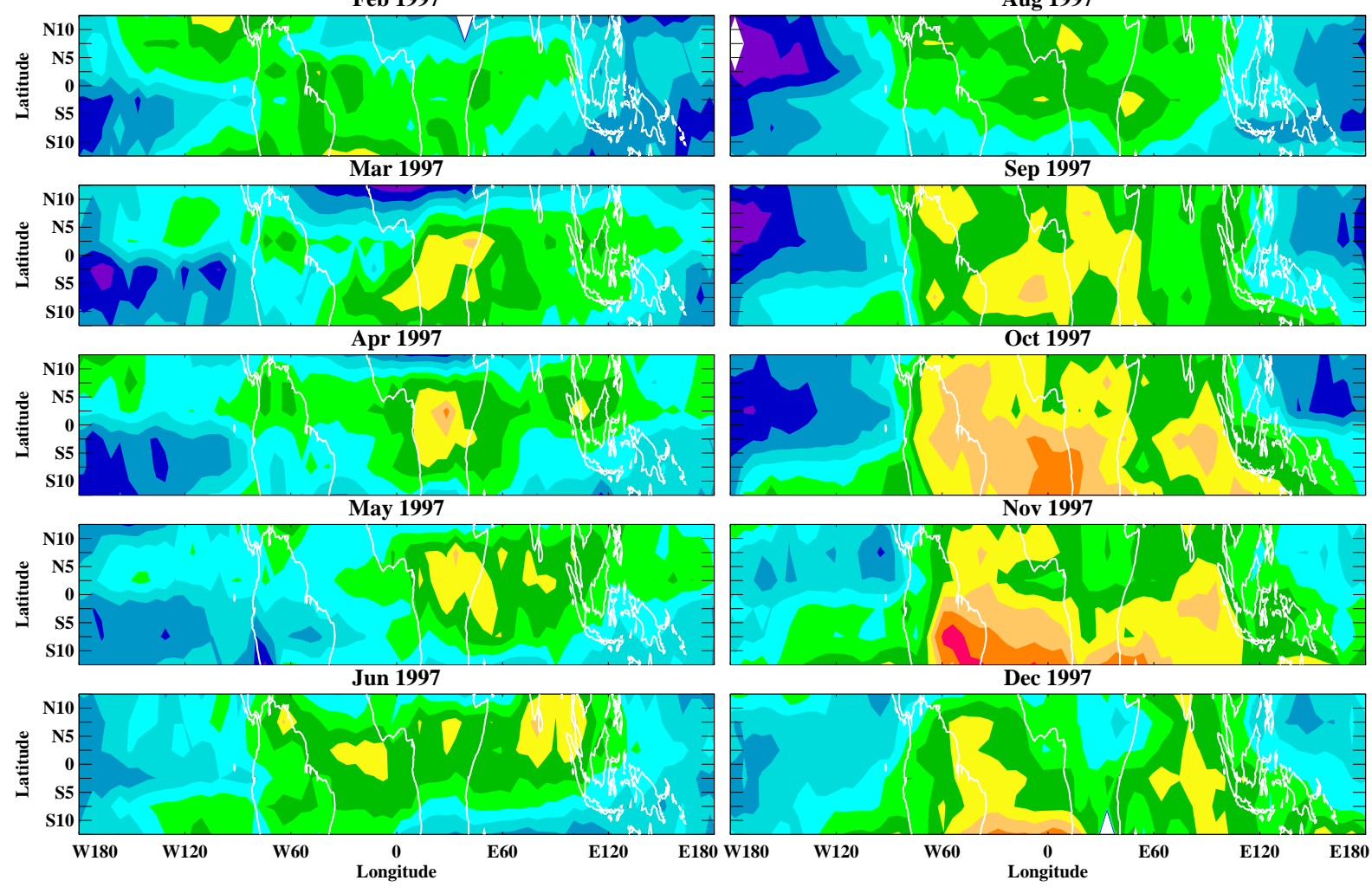

Longitude

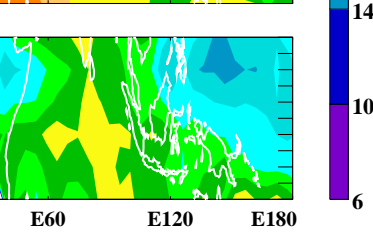

Fig. 9. CCP tropospheric ozone derived with EP TOMS 360-nm reflectivity information in 1997.

CCP method. Overall the archived CCD tropospheric ozone column results are $9 \pm 1$ SEM DU higher than all SHADOZ stations, on average, while the CCP results are $3 \pm 1$ SEM DU higher. Because upper tropospheric ozone over the Pacific ocean is relatively low, the omission of these cloud effects in the CCD method is fortuitously less significant than it would have been over the Atlantic ocean.

\subsection{Results}

CCP tropospheric ozone amounts and maps for 1979-2000 (excluding 1994-1995) and error correction data are available at http://vortex.nsstc.uah.edu/atmchem. Figure 8 displays the CCP tropospheric ozone derived with THIR and reflectivity in 1979 . We can see that the maximum tropospheric ozone ( $\sim 50 \mathrm{DU})$ occurs in July to November in the south Atlantic with evidence of increased amounts in northern equatorial Africa in December. The western Pacific experiences the lowest tropospheric ozone (minimum $\sim 10 \mathrm{DU}$ ) with relatively less annual variation. Figure 9 indicates the CCP tropospheric ozone derived using the reflectivity mea- surement without THIR cloud data in 1997. The highest ozone in this year occurs in the Indonesian areas, a result of forest fires and El Niño (Ziemke and Chandra, 1999). Ozone amounts are significantly higher from South America to Indonesia throughout the biomass burning season of OctoberNovember.

Figure 10 displays the 20 -year monthly climatology of tropospheric ozone for 1979-2000 using the reflectivity measurement for cloud detection. The climatology of monthly tropospheric ozone from 1979-1984 using the THIR cloud data is very similar to that using the reflectivity data only. This climatology indicates persistent Pacific Ocean ozone amounts of 15-20 DU and seasonally varying ozone amounts of $30-40 \mathrm{DU}$ in the Atlantic region. Individual months and locations show greater variations and extremes.

\section{Conclusions}

The Clear-Cloudy Pair (CCP) method derives tropical tropospheric ozone amounts from differences between TOMS 

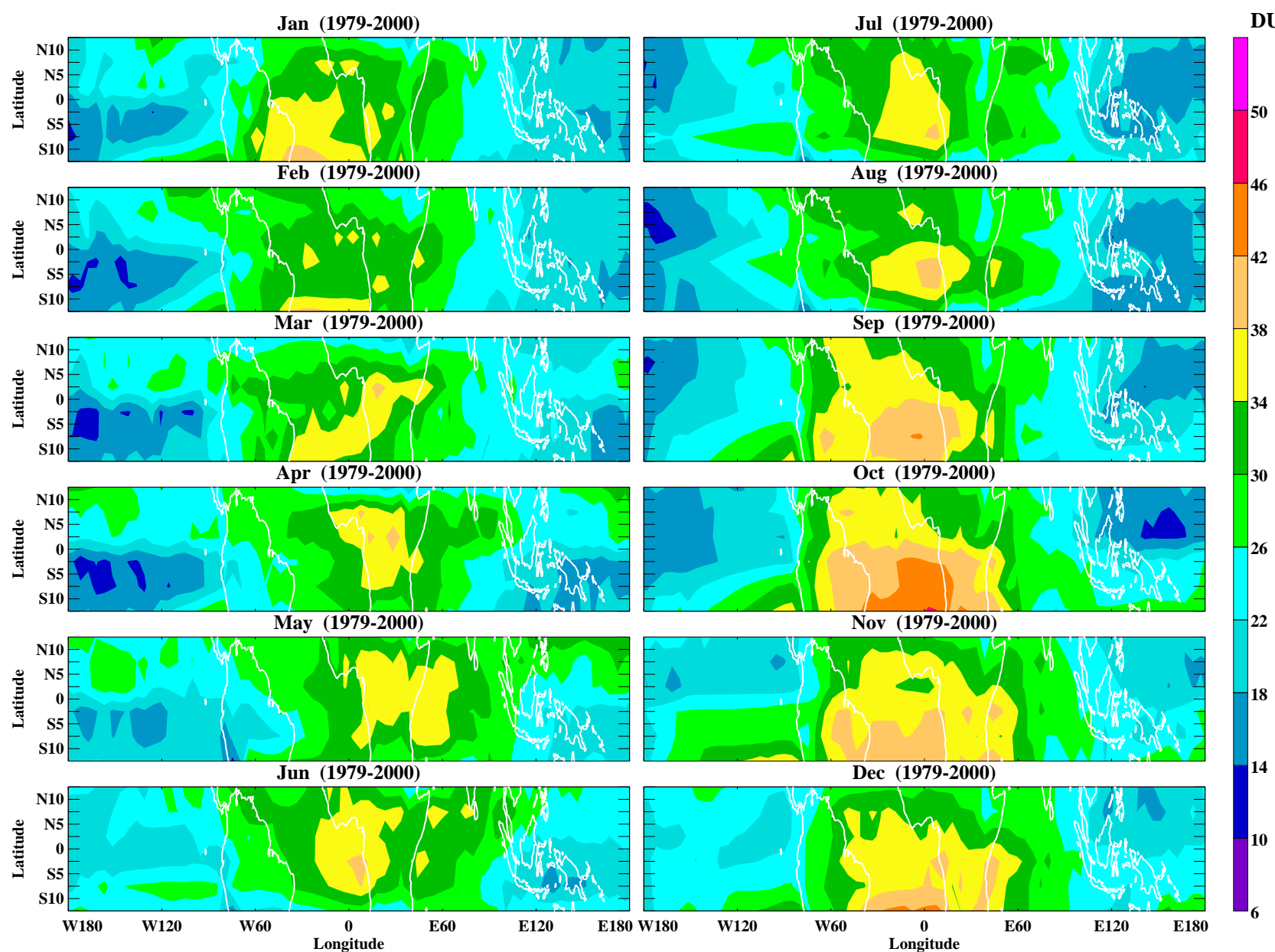

Fig. 10. Climatology of tropospheric ozone derived from the CCP method without THIR information between 1979-2000.

observations of stratospheric ozone over high-altitude clouds and clear columns. Accounting for the zonally varying stratospheric column improves agreement between these derived columns and collocated ozonesonde columns. Although using cloud heights measured by the Temperature Humidity Infrared Radiometer (THIR) sensor (1978-1984) is more accurate than using the TOMS $380-\mathrm{nm}$ reflectivity observations alone, using the 380-channel measurements as an approximation for high altitude clouds results in very similar tropospheric ozone columns. Comparison to 6 ozonesonde station observations indicates an average agreement in the tropospheric columns of $0 \mathrm{DU}$, varying from station to station between -3 and $2 \mathrm{DU}$ with standard errors of the mean of $\sim 1 \mathrm{DU}$. Results for individual months as well as climatologies over the 6-year THIR period and the 20year TOMS period are available at http://vortex.nsstc.uah. edu/atmchem/.

Acknowledgements. We are grateful for support of this research through the NASA/ACMAP and the international collaboration with the Korean Ministry of Science and Technology. We thank S. Chandra, J. Ziemke, P. K. Bhartia, C. G. Wellemeyer,
R. D. Hudson, and R. D. McPeters for enlightening discussions concerning use of convective clouds to derive tropospheric ozone. SHADOZ (Southern Hemisphere ADditional OZonesondes) data was obtained from http://hyperion.gsfc.nasa.gov/Data_ services/shadoz/Shadoz_hmpg2.html, CCD data was obtained from http://code916.gsfc.nasa.gov/People/Ziemke/.

\section{References}

Eck, T. F., Bhartia, P. K., Hwang, P. H., and Stowe, L. L.: Reflectivity of earth's surface and clouds in ultraviolet from satellite observations, J. Geophys. Res., 92, 4287-4296, 1987.

Fishman, J. and Balok, A. E.: Calculation of daily tropospheric ozone residuals using TOMS and empirically improved SBUV measurements: Application to an ozone pollution episode over the eastern United States, J. Geophys. Res., 104, 30 319-30340, 1999.

Fishman, J. and Brackett, V. G.: The climatological distribution of tropospheric ozone derived from satellite measurements using version 7 Total Ozone Mapping Spectrometer and Stratospheric Aerosol and Gas Experiment data sets, J. Geophys. Res., 102, 19275-19278, 1997. 
Fishman, J., Brackett, V. G., Browell, E. V., and Grant, W. B.: Tropospheric ozone derived from TOMS/SBUV measurements during TRACE A, J. Geophys. Res., 101, 24 069-24 069, 1996.

Fishman, J., Watson, C. E., Larsen, J. C., and Logan, J. A.: Distribution of tropospheric ozone determined from satellite data, J. Geophys. Res., 95, 3599-3617, 1990.

Herman, J. R., Celarier, E., and Larko, D.: UV $380 \mathrm{~nm}$ reflectivity of the Earth's surface, clouds and aerosols, J. Geophys. Res., 106, 5335-5351, 2001.

Herman, J. R. and Celarier, E. A.: Earth surface reflectivity climatology at 340-380 nm from TOMS data, J. Geophys. Res., 102, $28003-28011,1997$.

Hudson, R. D., Kim, J.-H., and Thompson, A. M.: On the derivation of tropospheric column from radiances measured by the Total Ozone Mapping Spectrometer, J. Geophys. Res., 100, $11137-$ $11145,1995$.

Hudson, R. D. and Thompson, A. M.: Tropical tropospheric ozone from Total Ozone Mapping Spectrometer by a modified residual method, J. Geophys. Res., 103, 22 129-22 145, 1998.

Hwang, P. H. Ed.: Nimbus-7 Temperature Humidity Infrared Radiometer (THIR) data user's guide, NASA/ Goddard Space Flight Center, Greenbelt, MD 20771, 52, 1982.

Jiang, Y. and Yung, Y. L.: Concentrations of tropospheric ozone from 1979 to 1992 over tropical Pacific South America from TOMS data, Science, 272, 714-716, 1996.

Kim, J. H., Hudson, R. D., and Thompson, A. M.: A new method of deriving time-averaged tropospheric column ozone over the tropics using Total Ozone Mapping Spectrometer (TOMS) radiances: Intercomparison and analysis using TRACE-A data, J. Geophys. Res., 101, 24 317-24 330, 1996.

Kim, J. H. and Newchurch, M. J.: Climatology and trends of tropospheric ozone over the eastern Pacific Ocean: The influences of biomass burning and tropospheric dynamics, Geophys. Res. Lett., 23, 3723-3726, 1996.

Kim, J. H. and Newchurch, M. J.: Biomass-burning influence on tropospheric ozone over New Guinea and South America, J. Geophys. Res., 103, 1455-1461, 1998.

Kim, J. H., Newchurch, M. J., and Han, K.: Distribution of Tropical Tropospheric Ozone determined by the scan-angle method applied to TOMS measurements, J. Atmos. Sci., 58, 2699-2708, 2001.

Liu, X., Newchurch, M. J., and Kim, J. H.: Occurrence of Ozone Anomalies over Cloudy Areas in TOMS Version-7 Level-2 Data, J. Atmos. Chem. And Phy., Submitted, 2002.

Martin, R. V., Jacob, D. J., Logan, J. A., Bey, I., Yantosca, R. M., Staudt, A. C., Li, Q., Fiore, A. M., Duncan, B. N., Liu, H., Ginoux, P., and Thouret, V.: Interpretation of TOMS observations of tropical tropospheric ozone with a global model and in-situ observations, J. Geophys. Res., 107(D18), 4351, 10.1029/2001JD001480, 2002.

McPeters, R. D., Bhartia, P. K., Krueger, A. J., Herman, J. R., Schlesinger, B. M., Wellemeyer, C. G., Seftor, C. J., Jaross, G., Taylor, S. L., Swissler, T., Torres, O., Labow, G., Byerly, W., and Cebula, R. P.: Nimbus-7 Total Ozone Mapping Spectrometer (TOMS) Data Products User's Guide, 67, NASA, Washington, D.C., 1996.
Newchurch, M. J., Liu, X., Kim, J. H., and Bhartia, P. K.: On the accuracy of TOMS retrievals over cloudy regions, J. Geophys. Res., 106, 32 315-32 326, 2001a.

Newchurch, M. J., Sun, D., and Kim, J. H.: Zonal wave-1 structure in TOMS tropical stratospheric ozone, Geophys. Res. Lett., 28 , 3151-3154, 2001b.

Smith, A. K. and Riese, M.: Cryogenic Infrared Spectrometers and Telescopes for the Atmosphere (CRISTA) observations of tracer transport by inertially unstable circulations, J. Geophys. Res., 104, 19 171-19 182, 1999.

Stanford, J. L., Ziemke, J. R., McPeters, R. D., Krueger, A. J., and Bhartia, P. K.: Spectral analyses, climatology, and interannual variability of Nimbus-7 TOMS version 6 total column ozone, Bulletin of AMS, 77, 353-357, 1996.

Stowe, L. L., Wellemeyer, C. G., Eck, T. F., Yeh, H. Y. M., Hwang, P. H., Kyle, H. L., Pellegrino, P. P., Yeh, H. Y. M., and Eck, T. F.: Nimbus-7 Global Cloud Climatology. Part I: Algorithms and Validation, J. of Climate, 1, 445-470, 1988.

Thompson, A. M. and Hudson, R.D.: Tropical tropospheric ozone (TTO) maps from Nimbus 7 and Earth Probe TOMS by the modified-residual method: Evaluation with sondes, ENSO signals, and trends from Atlantic regional time series, J. Geophys. Res., 104, 26961-26975, 1999.

Thompson, A. M., Oltmans, S. J., Schmidlin, F. J., Logan, J. A., Fujiwara, M., Kirchhoff, V. W. J. H., Posny, F., Coetzee, G. J. R., Hoegger, B., Kawakami, S., Ogawa, T., Johnson, B. J., Vömel, H., and Labow, G.: The 1998-2000 SHADOZ (Southern Hemisphere ADditional OZonesondes) Tropical Ozone Climatology: Comparison with TOMS and Ground-based Measurements, J. Geophys. Res, in Press, 2003.

Thompson, A. M. and Witte, J. C.: SHADOZ (Southern Hemisphere ADditional OZonesondes): A new data set for the Earth science community, Earth Obs., 11, 27-30, 1999.

Torres, O. and Bhartia, P. K.: Impact of tropospheric aerosol absorption on ozone retrieval from backscattered ultraviolet measurements, J. Geophys. Res., 104, 21 569-21 577, 1999.

Wellemeyer, C. G., Taylor, S. L., Seftor, C. J., McPeters, R. D., and Bhartia, P. K.: A correction for total ozone mapping spectrometer profile shape errors at high latitude, J. Geophys. Res., 102, 9029_ 9038, 1997.

Ziemke, J. R. and Chandra, S.: Seasonal and interannual variabilities in tropical tropospheric ozone, J. Geophys. Res., 104, 21 425-21 442, 1999.

Ziemke, J. R., Chandra, S., and Bhartia, P. K.: Two new methods for deriving tropospheric column ozone from TOMS measurements: Assimilated UARS MLS/HALOE and convective-cloud differential techniques, J. Geophys. Res., 103, 22 115-22 127, 1998.

Ziemke, J. R. and Stanford, J. L.: Kelvin waves in total column ozone, Geophys. Res. Lett., 21, 105-108, 1994. 